\title{
Looking back and going forward: the concept of the public in public relations theory
}

'Where all think alike, no one thinks very much.' (Walter Lippmann, The Stakes of Diplomacy, 1915)

'To act in concert does not mean to act in conformity' (Judith Butler, Notes Toward a Performative Theory of Assembly).

This paper contributes to the discussion of fundamental questions for public relations theory by examining a particular, one could say, foundational concept in public relations, namely the public. In its origins, the notion of the public as a collective entity with legitimacy to act on matters of politics, economy, and culture is rooted in the Protestant Revolution in the $17^{\text {th }}$ century England and the Enlightenment thought reflected in the development of modern democratic systems of government (Price, 2008). However, for nearly fifty years now researchers have argued that democracy is in decline (Crozier et al, 1975) and more recently, in crisis (Bauman and Bordoni, 2014; Thomassen, 2015, see also Cronin 2018). This is part of a more profound change we have been witnessing. Social scientists have increasingly come to rely on the concept of network to understand the complex and fluid dynamics of social life and politics in the globalised world that is increasingly shaped by digital communication technologies (Castells 1996; White, 2008; van Dijk et al 2018; Lee 2017). At the core of the current research that cuts across sociology, politics, and communication is the question of how people come to act together in this new changing world. In search for an answer Bennett and Segerberg extended the existing approach to the study of collective action (Olsen, 1965) by introducing an additional category of connective action in which digital media act as 'organizing agents' and participation becomes the sharing of 'personally expressive content' across networks (Bennett and Segerberg, 2012: 752). In face of such changes, it is necessary to interrogate anew the 
old concept of the public as the corner stone of public relations theory: How adequate is it for public relations inquiry in the network, platform society?

This paper provides an overview of the way in which public relations has understood the term as referring to two distinct phenomena $a$ public and the public. This discussion acts as a springboard for inquiry into two specific interests. Firstly, the paper approaches public relations theory as a kind of unfolding of a narrative identity of public relations, understood as acts of creating and remaking public relations as a disciplinary practice. Disciplinary practice is used here both in the traditional and in the Foucauldian sense, i.e. as a distinct specialist area of knowledge but also as a set of normalizing practices (Anderson and Grinberg, 1998; Foucault, 1979/1991). Secondly, the paper considers the limitations and implications of the deliberativist approach to the public derived from the work of John Dewey and Jurgen Habermas where the public is defined by a particular mode of appearance (reasonbased, open, collaborative, and self-reflective) tied to particular linguistic ways of acting, such as deliberation, debate and discussion (Mansbridge et al, 2006). In its final sections, the discussion turns to the idea of public discourse and performativity (Butler, 2010) to redefine the concept of the public and to draw out conclusions for public relations theory.

\section{Public relations discovers the public}

Despite some textbook histories stretching back to the Babylonians to show a long line of organized uses of communication for the achievement of political, economic of cultural aims as a kind of protoPR (Cutlip and Center, 1978), the origins of public relations as a distinct occupational practice can be located in the division of labour in the modern capitalist, industrial, mass democracies of the 19th century with communication specialists serving both the industry and the state (Myers, 2017; Fitch and L'Etang, 2017). As such, it is also inextricably linked to both the technologies of mass communication and the political legacy of the Enlightenment attached to the idea of the public - a collective noun for the rational and autonomous citizens of a modern polity (Lippmann, 1925; Dewey 1927; Wernick, 1991; Habermas 1996, 2006; Jackall and Hirota, 2000; Bohman, 2004). The origins of public relations' preoccupation with the idea of the public can be located in the same political and 
intellectual milieu as the intense debate about the public itself, its nature, role, and capacity for democratic governance in the 1920s and 30s America. Here John Dewey's work The Public and Its Problems (1927/2012) articulated the idea of the public as a response to 'the crisis of democracy' created by a combination of: the secularization of politics; the blow delivered to the idea of progress by the industrialized slaughter of World War I; and the application of psychology and mass communication to politics in the form of propaganda (Rogers 2012:13-14). Equally importantly, however, Dewey's work responded to Walter Lippmann's, rather different, view of the public and public opinion $(1922,1925)$, in what is now referred to as the Dewey-Lippmann debate (Mason, 2017; Carey, 1989; Johnston and Pieczka, 2019). It is in this context that we can situate Edward Bernays' work of developing the idea of public relations as a 'pro-social propaganda' (St. John and Lamme, 2011). His books Crystallizing Public Opinion (1923) and Propaganda (1928) were clearly framed by the concerns of the Dewey-Lippmann debate and in presenting public relations practitioners as public communication experts Bernays echoed Lippmann's belief in experts as rightful managers of public affairs.

Dewey's conceptualization of the public is well known and has attracted much attention and comment from communication scholars (Carey, 1989; Peters, 1989; Schudson, 2008). The public is the focal point in Dewey's political thought. Writing at a time of political strain, he argued that the foundation of vigorous democracy lies in practical political action, i.e. collaboration and deliberation undertaken by citizens. He called this phenomenon the public, explaining it as follows:

Conjoined, combined, associated action is a universal trait of the behavior of things. Such association has results. Some of the results of human collective action... are noted in such ways that they are taken account of. Then there arise purposes, plans, measures and means, to secure consequences which are liked and eliminate those which are found obnoxious. Thus perception generates a common interest. ... Those .... affected for good or evil form a distinctive enough group to require recognition and a name. The name selected is The Public. (Dewey, 2010: 58) 
A number of other important conditions and implications that Dewey articulated need to be added to this definition. His writing distinguished between the public and a public. The public appears to be something of an ideal-type rather than an empirical phenomenon. A public, on the other hand, is concrete and embodied; there are, in fact, multiple such publics in any society. Yet, even $a$ public is hard to pin down due to the duality of its nature, oscillating between the individual and the collective, between 'I' and 'we':

Singular persons are foci of action, mental and moral, as well as overt. They are subject to all kinds of social influences which determine what they can think of, plan, choose. The conflicting streams of social influence come to a single and conclusive issue only in personal consciousness and deed. When a public is generated, the same holds true. It arrives at decisions, makes terms, and executes resolves only through the medium of individual.... The public is here a collective name for a multitude of persons... As a citizen-voter each of these persons is, however, an officer of the public.... In other words, every officer of the public, whether he represents it as a voter or a state official, has a dual capacity. (Dewey, 2012: 81) We could say thus that a public is in some respects plain to see, but that there is also more to it than can be seen: it is a combination of the empirical and the symbolic, of action and imaginative commitments.

For Dewey the public is a fundamental political concept: without the understanding of the public, there is no proper understanding or transformation of the state (p. 60). The public requires communication as a prerequisite to participation (p.123), and it demands publicity, which could be interpreted as public communication, to obtain knowledge and understanding of itself ( $\mathrm{p} .132)$. Thus the public combines individual consciousness and interest with a form of collective existence, and it bears an indelible political imprint. Dewey's political philosophy sees democracy as rooted in a particular vision of the individual and of reason. Unlike Lippmann, he does not view the autonomous individual as being in tension with society, but rather as inherently social (Rakow, 2018: 317). For him reason is understood not as an individual's capacity for inquiry and judgment, but rather as a 
social phenomenon in which inquiry and judgement are formed in an intersubjective manner (Johnston and Pieczka, 2019).

It was, however, Lippmann's rather than Dewey's ideas that were most influential in the formation of public relations in the first half of the 20th ${ }^{\text {th }}$ century (Stoker, 2014). Dewey made it into public relations textbooks with the first edition of Cutlip and Center's Effective Public Relations in 1952, which according to Rakow (2018) marked the beginning of the systematic misinterpretation of his work in the field of public relations. She focused on the treatment Dewey received across the various editions of Effective Public Relations, a textbook important for the international circulation of the emerging public relations knowledge ${ }^{1}$, and highlighted the shift of attention away from the idea of the public to that of publics, in the plural. A key point in this process, she argued, was the definition of a public, known probably to every student of public relations, that made a selective use of Dewey: 'a group of individuals who together are affected by particular action or idea. Thus each issue or problem creates its own public' (Cutlip and Center, 1971:128 cited in Rakow, 2018: 323). Public relations theory thus lost sight of the bigger political frame that tied democracy and communication to the public and fixed its attention on organizational effectiveness and the management of publics for organizational benefit (Leitch and Neilson, 2001). While Dewey's understanding of The Public as a model of the political phenomenon at the core of a democratic state receded out of view with the assertion that there is was no such thing as the general public (Grunig and Hunt 1984:138; Cutlip at al 1994: 360), a public appeared at the centre of public relations theory. It was defined as a collection of individuals who share specific psychographic characteristics that explained their individual communication behaviour (Larsson 2006:127; Leitch and Neilson, 2001:131). Furthermore, a

\footnotetext{
${ }^{1}$ According to WorldCat, Effective Public Relations had 137 editions between 1952 and 2009, it was published in a number of languages and held in 3,117 WorldCat member libraries around the world. There is a Chinese translation published in 1998 and 2001. The first Spanish translation appeared in 1975, followed by new editions in 2000 and 2006 with Spanish co-authors. Cutlip also co-authored related textbooks in Italian (14 editions between 1960 and 2003) and in Japanese, published in 1974 and 2008. (http://www.worldcat.org/identities/lecn-n81098196/).
} 
typology of publics was offered. Each public could only be one of the four possible types: non-public, latent, aware or active public; each was defined as a pattern constituted by three independent and two dependent variables (Grunig and Hunt, 1984: 143-160 ). In short, what the theory explained was how individuals' communicative behaviour (information seeking or information processing) was produced by a combination of their problem recognition, constraint recognition, and level of involvement. This explanation consequently did not deal with the collective as an entity or as a level of analysis: the public appeared to be merely a sum of individuals, each reading the world from their own particular position. Rakow's discussion of Situational Theory of Publics (STP) positioned it as a disciplinary tool that normalized the reductive shift away from the public in the Deweyan political and collective sense to a public as an 'information processing system' (2018: 323).

\section{Public relations theory: between public and stakeholder}

It can be argued that the attention given to the idea of a/the public signalled theoretical ambitions in the field of public relations as did its responsiveness to developments in other disciplines, illustrated for example by the borrowing of the idea of excellence (McKie and Munshi, 2007). The term stakeholder, also adopted from business (Freeman, 1984; Mackey, 2006 ), became closely linked to that of a public in Grunig and Hunt's (1984) textbook exposition of STP and again in Grunig and Repper's (1992) chapter in the first outing of the theory of excellence in public relations (see also Aldoory and Sha, 2007; Grunig, 2011). The appearance of stakeholder signals not only the field's theoretical alertness, it should also be seen as symptomatic of the direction of change in public relations theory development discussed above: the simultaneous objectifications of the individual through technicization of the expert approach combined with the erasure of the collective as a meaningful entity in its own right.

Although intended to be distinct, the two concepts came to be used interchangeably to the extent that a clarification became necessary for the benefit of public relations knowledge institutionalized under the auspices of the Institute for Public Relations, a US professional body. 
The terms stakeholder and public are often used interchangeably, but they shouldn't be.

Stakeholders have been identified in the business literature according to their relationships to organizations. Publics, in the public relations and other mass media literature, are often identified according to their relationship to messages. (Rawlins, 2006:1)

The paper further pointed to Grunig's own explanation which saw stakeholders as created by organizational strategies, while publics arose 'on their own' (Grunig and Repper, 1992:128) 'from the ranks of stakeholders when they recognize[d] an issue and decide[d] to do something about it' (Rawlins, 2006: 3). The usage of these two terms, however, continued to be problematic in ways that are of interest to this discussion. Firstly, the distinction appeared hard to maintain, as illustrated by Grunig's own reference to 'stakeholder publics' (2011:16), an overlexicalization as his definition makes non-stakeholder publics impossible. Secondly, the term stakeholder could be seen as colonizing 'aspects of existing language' and 'crowding out' other terms such as a public (Mackey, 2006:1).

Without a detailed bibliometric analysis, it is hard to say more than that the term has become well entrenched in public relations and used extensively since 2006 when Mackey's paper was published. Some support for Mackey's thesis can be derived from the fact that unlike stakeholder and audience, public does not appear in the language of professional competencies as defined, for example, by the Government Communication Service in the UK (GCS, 2016), and that it appears marginal for the Global Alliance's Global Body of Knowledge (GBOK), represented by one mention, part of a seniorlevel research competency:

Audience Identification: Differentiates among publics, markets, audiences and stakeholders. Identifies appropriate audiences and the opinions, beliefs, attitudes, cultures, and values of each. Assesses interests of influential institutions, groups and individuals. Identifies appropriate communication channels/vehicles for reaching target audiences. (KSAB list) 
A salient question to ask at this point is how to interpret such conceptual preferences. This paper argues that the debate about these terms should be taken as symptomatic of deeper tensions to do with how public relations constructs itself and its place in society through theoretical preferences. This is well demonstrated by the juxtaposition of Mackey's rejection of stakeholder and Grunig's own justification for his rejection of the public.

Mackey's argument against the replacement of the noun public with stakeholder is mounted from a normative position. Firstly, he highlighted the ideological dimension of the stakeholder as a concept and its theoretical expression in the stakeholder theory: it is 'managerialist' and 'primarily concerned with the dispositions and wants, the particular interests, of particular groups of people' (p.12). Secondly, he argued that the stakeholder theory ultimately operated to re-enforce structures of power, obligation and patronage. On the other hand, he viewed the public as rooted in ideas such as the lifeworld (Habermas, 1984) and MacIntyre's virtue (1981), thus ultimately pointing to the importance of shared human practices in providing meaning, value, and sustaining both collective and individual good life.

What we might call 'public relations theory' does not court or patronise [particular interests]. It operates at the level of citizen and the commoner. Public relations counsel understands the segmentation of the public and also understands and respects different publics' variety of interests. But public relations professionals... consider how all interests —including those derived outside dominant business or political ideologies - fit into the whole cultural, ethical and political picture (Mackey, 2006:13)

The public emerged in his discussion as the appropriate concept for public relations theory because of its specific political nature and commitments: it is the imagined community of citizens.

Grunig, on the other hand, rejected the idea of the public, ostensibly on the basis of its impracticability:

It may be true that organizations must be concerned about society-at-large, which Krukenberg and Vujnovic (2010) equate with a 'general public'. However, I do not consider 'society-at- 
large' to be a public. It is a collection of publics. Every person on Earth cannot be concerned about every organization on Earth. Thus, I believe organizations contribute the most to society-at-large when they work with people they actually affect and solve the problems with which they are involved. (2011:19)

This argument works by appealing indirectly to a well-known idea in political philosophy that praises the value of small-scale individual endeavour as the engine of societal prosperity, i.e. economic wealth and common good. I refer here specifically to the way in which Adam Smith in The Wealth of the Nations and The Theory of Moral Sentiments grounded national prosperity in the economic activity driven by, on the one hand, individual self-interest and, on the other hand, by the Invisible Hand that transforms such self-interested activity into national wealth. While Smith did not offer one definitive version of the Invisible Hand idea (Schliesser, 2017), Milton Friedman interpreted Smith by claiming that individuals' economic activity and trade was sufficient 'to make everyone better off'-the core of his free-market capitalism (Friedman, 1980: 5 cited in Macleod, 2007: 107). Unlike Smith, Friedman claimed that the public interest, and indeed we can say the public itself, was an automatic consequence of individuals' pursuit of their own interests and that it demanded nothing else but the removal of constraints on their ability to do so. Grunig's passage quoted above aligns, intentionally or not, with neoliberalism, and in doing so dispenses with the idea of both the public and the state. According to this account, public relations should perhaps be more accurately named stakeholder relations.

We can now differentiate between two main positions in public relations theory. Firstly, there is the view underpinned by Habermas's philosophy that continues the preoccupations found both in the Enlightenment thought (equality, justice, reason) and the Frankfurt School (power, ideology and knowledge, emancipation in a capitalist society) and that consequently retains the sense of the public (Burkart 2018; Edwards 2016; Toledano, 2016; Demetrious, 2013; Mackey 2006; Leitch and Neilson, 2001). Despite differences between them, it is important to note here Dewey's influence on Habermas (Calhoun, 2013; Rakow, 2018) and therefore to treat their work as a continued development. Secondly, there is the approach underpinned conceptually and methodologically by human 
communication, grounded in psychology rather than philosophy, politics and language, and identified here with the Situational Theory of Publics (Kim and Ni, 2013; Aldoory and Sha, 2007; Grunig, 2011; Grunig and Repper 1992). It defines a public and deals with it as a collection of individuals rather than a collective entity underpinned by collective dynamics or characteristics. However, developments in the theory of the public sphere itself, encompassing critiques that addressed exclusions from Habermas's original definition of the bourgeois public sphere as well as the dynamics of fragmentation, virtualization and upscaling to transnational dimensions (Edwards, 2018:104-119), created an in-between space where the multiple publics co-exist and the mini- and macro- levels of analysis are joined coherently by the deliberativist treatment of so called mini-publics, such as Consensus Conferences, Deliberative Polls, or Citizen Juries (Goodin and Dryzek, 2006: 220).

The intention of this article is not only to look back at the route that has brought public relations theory to this particular place, but to go beyond it. The following two sections attempt to do so by drawing on the work of Warner and Butler to offer a definition of the public and a typology of the publics that responds to the current state of knowledge about communication and collective action.

\section{Beyond the theoretical dichotomy}

The theoretical dichotomy identified in the previous section between the approach that prioritizes the existence of the public sphere and that which prioritizes the neo-liberal 'market society' (Demetrious and Surma, 2019: 105) has powered both critiques and defences of public relations (for overview see Edwards, 2018:104-119). Cronin's Public Relations Capitalism (2018) continues the public spherebased critique by positioning public relations not simply as an intermediary but as the key agent in the deepening reach of promotional logic in society. She refers to the resulting phenomenon as 'commercial democracy', 'a new relationship between political culture and commercial culture' (Cronin 2018:1). To accomplish her task, Cronin brought Michael Warner's Publics and Counterpublics (2005) into the discussion of public relations to argue that 'PR creates publics' (p. 3) rather than serves the public or manages publics, as habitually claimed within the field itself. I will follow her lead in offering a reading of his ideas, before moving on to discuss the role of discourse, 
formation of subjectivity, performance and performativity in relation to the idea of the public as the key concept in public relations theory.

Warner's discussion starts with an acknowledgment of the paradox of the simultaneous importance of publics in modern life and the obscurity of the idea. Like anyone writing about the topic in English, he has to contend not just with the somewhat slippery nature of the phenomenon, but also with the way in which the English language — with its definite and indefinite articles — adds to this difficulty (see Rogers, 2012: 25). Warner begins by distinguishing between the public, and $a$ public. The first is 'a kind of social totality... the people in general. It might be people organized as the nation, the commonwealth, the city, the state or some other community' (2005: 65). In its other sense, that of $a$ public, it is equated with 'a concrete audience, a crowd witnessing itself in a visible space, as with a theatrical public' (p. 66). Warner's main preoccupation, however, is with the third meaning of the word: 'the kind of public that comes into being only in relation to texts and their circulation' (p.66). Before more explanation is offered about this idea of a public, it is important to stress that for Warner the three senses of the noun public can and do at times overlap, not because the concept is inadequately defined, but rather because such usage reflects the way in which we operate between the 'I' and 'we', the individual and the collective, in different spheres and situations of social life.

To explore this third meaning of a public Warner returns to Habermas's idea of the 'reading public', the basis for the public sphere as it emerged in the late seventeenth and early eighteenth century (pp. 46-47). For the purposes of this discussion, I set aside debates about the public sphere, and keep 'the reading public' as a helpful analogy. Warner explains the way in which this kind of public arises and persists by giving it the following characteristics (pp. 65-124):

1. A public is self-organised;

2. It is a relation among strangers 'implied by a public's self-organization through discourse' (p.74)

3. The address of public speech is both personal and impersonal

4. A public is constituted through mere attention 
5. A public is the social space created by the reflexive circulation of public discourse

6. Publics act historically according to the temporality of their circulation

7. A public is poetic world making

Some of these statements are more familiar than others in the context of the discussion so far. For example, the self-organization of the public or its ontological and epistemological dependence on discourse has already been discussed, as has the duality of its nature, oscillating between the individual and the collective. What is new is Warner's explicit recognition of the performative nature of a public that is derived from the nature of public discourse: its pretence to be addressing an already existing public nestled within its lifeworld when both the public and its postulated world come into being in response to such an address.

Public speech lies under the necessity of addressing its public as already existing persons. It cannot work by frankly declaring its subjunctive-creative project. Its success depends on the recognition of participants and their further circulatory activity, and people commonly don't recognize themselves as virtual projections. (Warner, 2005:114)

Warner's argument here is that texts not only call out for attention but that they have a performative dimension, they make the world into which a public will come and respond in ways indicated by the text itself: 'Public discourse says not only "Let a public exist" but "Let it have this character, speak this way, see the world in this way" (2005: 114). This performative, poetic feature of a public draws attention to the essentialist bias in public relations theory noted by Winkler and Wehmeier (2018). The scholars argued that public relations research treats organizations, stakeholders, and publics as defined by STP, 'as pre-given social identities with particular attributes and attitudes' (p. 146). In doing so, it misses the performative dynamic of a public ${ }^{2}$ where identities and relationships arise out of contextual negotiations within a network.

\footnotetext{
${ }^{2}$ Winkler and Wehmeier's argument was advanced in the context of the relevance of Harrison White's sociology for public relations. Consequently, they used the term public in the way in which it functions in White's sociology, very different from meanings presented in this discussion so far (see Winkler and Wehmeier, 2018: 152). Consequently, in their critique of public relations theory they focused on the concept of stakeholder, which they understood in the same way in which a public was understood in the Situational Theory of Publics.
} 
Instead of two competing and hard to reconcile conceptions of a/the public, we now have three conceptually distinct but practically overlapping, or at least coexisting entities: Audience as a collective with some element of physical connection or shared space; the self-organised public arising in response to circulation of texts; and finally, the imagined public, a macro-level phenomenon such as the nation, community or society, that may have some institutional infrastructure but tends to be deployed to signify the idea more than the reality of unity or commonality.

To illustrate this scheme of coexisting conceptions of the public, let me offer a personal example. A few months ago Prof Judith Butler delivered three lectures in the Glasgow University's Gifford Lectures series; I was in the audience. The audience, visible in the video record of the event ${ }^{3}$, was gathered in a physical space and consisted mostly of scholars and students of more than one university. The audience enacted its shared presence in ways appropriate to this type of event with clearly defined rules governing individual and collective actions such as speaking, listening, physical movement, as well as the relationship between the speaker and the audience, and between the members of the audience. I was part of that audience because I chose to be. I did not know anybody there, which did not seem to be that uncommon amongst the audience: many of us were strangers. Listening to questions from the audience, it is possible to guess at some of the reasons for participation. While not everybody was there for exactly the same reason, it was broadly a sympathetic audience, unlike audiences in some town hall meetings, for example. I was there because I consider myself to be a member of a public concerned with the issue of human autonomy and social justice under the conditions of neoliberalism and globalization. My membership in this putative public is based on my attention to and on my recognition of certain texts that have been circulating publicly, some of them since the 1990s. In brief, this public and my belonging to it is predicated on a discourse that I personally locate in my reading of Zygmunt Bauman's and Judith Butler's work. I know there

\footnotetext{
${ }^{3}$ This YouTube video is a record of the first lecture, including the pictures and voices of the audience. See https://www.giffordlectures.org/file/glasgow-gifford-lectures-judith-butler-1st-october-2018
} 
are many people who are members of this 'human autonomy and social justice under conditions of neoliberalism and globalization' public. They are strangers to me: I may never meet most of them but nevertheless I recognize them all as my fellows. When I speak about these matters in casual everyday conversations, I know there is more to it than, for example, my talk about things $I$ have to do in $m y$ teaching practice to accommodate marketization of education. I speak because it matters to me; I speak because I have and share a language in which to speak about it; but I also speak because I perform my membership of this public. I knew some of us would be in that lecture hall but I did not go to meet members of this public as individuals, or 'to network'. Rather, I hoped to take reassurance and pleasure from the presence of like-minded people.

My membership of this public is thus a matter of my subjectivity and its sociability, the coming together of the personal (tangible and material elements of my life) and the public (acts of imaginative partaking in the ideas shared through texts and discourses). My membership in this public is enabled by the poetic function of public discourse that "characterizes the world in which it attempts to circulate, projecting for that world a concrete and liveable shape, and attempting to realize that world through address' (Warner, 2002: 81). I thus knew what to expect from the speaker and for me attending the lectures was partly a way of acclaiming such ideas and sentiments. My silent participation thus made a point. Finally, it also has to be acknowledged now that another sense of the public was at work there as well: both explicitly and implicitly, the imagined public of society was a point of reference for the speaker and her audience. Whether all who spoke imagined society it in the same way is less important than the existence of that category for the audience and the publics present in the lecture hall. It provided the common ground for this meeting of people and ideas. We can see thus how the three distinct ways in which individuals enact a sense of the collective can be co-present.

To conclude this section concerned with adopting Warner's ideas in order to reflect on public relations theory, it is important to highlight texts and their circulation as fundamental concepts. Questions from the audience revealed that a range of texts and human circumstances, some unfamiliar to me, drew people into the lecture hall. Warner postulated that texts and their circulation are 
important to the constitution of a public and, having established their co-joint existence, we can now say, to the constitution of an audience. However, texts that bring people into a given public may not be the same. I named mine as specific academic texts; others might identify themselves with the same discourse by paying attention to different texts, for example, Quaker tradition, Ken Loach's films, or activist campaigns for transgender rights.

No single text can create a public. Nor can a single voice, a single genre, or even a single medium. All are insufficient to create the kind of reflexivity that we call a public, since public is understood to be an ongoing space of encounter for discourse. It is not texts themselves, but a concatenation of texts through time. (Warner, 2002: 90)

An audience, with its possibility of bringing multiple publics under one roof, may be organised as a response to an event, i.e. a 'text' in which they are all participating according to the accepted rules that govern such texts. In this example, the text is a public lecture, but given the speaker and her history of activism, it could have been a public protest. Thus the category of 'text' should be expanded beyond its traditional meaning of a written text that serves the reading public. Public relations practice has been bound to the circulation of written texts, i.e. journalistic and organizational genres of writing. This example shows how a text such as a public lecture can be curated as a video content and placed on a shared media platform to gain circulation independent of the original event. In reconceptualising the meaning of the public for public relations, it becomes necessary to reconsider the nature of texts public relations practitioners (co)create and circulate. I shall return to this point in the next section.

'Anything that addresses a public is meant to undergo circulation', says Warner in his remarks on the circulation of texts (2005: 90). His attention focused on the 'multigeneric lifeworld', i.e. the presence of different types of texts and their ways of circulating in the familiar everyday worlds of our lives. Digitalization of communication has added another layer of complexity to the phenomenon of circulation. In theorizing platform society, Van Dijck et al (2018: 33-37) discuss expert commercial practices related to circulation of digital data across platforms as one of the key elements of datafication, itself one of the basic operating mechanisms that underpin platforms. However, the 
technical means of data circulation are less important here than the effect this process creates: 'a new kind of consciousness - an "ambient virtual co-presence" where users are aware of what others are doing, experiencing and feeling' (p.36). In terms of public relations, we can consider this phenomenon to be at play, for example, in an unfolding of organizational crises, or in reputation building processes: they may be partly shaped by the presence of a digital ambient audience. Circulation of texts in the platform world depends on digital affordances and the overall platform ecology shaped by market dynamics in which the Big Five infrastructural platforms (Alphabet, Inc; Facebook, Inc; Apple Inc; Microsoft Corporation; Amzon.com, Inc) operate and compete (Van Dijck et al, 2018: 12-16). Although not discussed in such terms, the PESO (Paid, Earned, Shared, Owned) model of media use in public relations (Macnamara et al, 2016; Dietrich, 2014, 2018) is implicitly concerned with creation and circulation of a variety of texts, including those enabled by the digital technology, such as eye-witness personal footage, blogs, forms of online interaction, or memes, all with an eye to Search Engine Optimization. As such, PESO model should be recognised as contributing to the reconceptualization of the public and it should be used to underpin research to provide detailed empirical accounts of the interconnections between digital audiences, publics, texts, and circulatory practices.

\section{The performative approach to the public}

The discussion in the previous sections referred to the essentialist and normative approaches to the public and argued for the need to turn to the performative approach. The remaining two sections develop the argument further by defining performativity, applying it to public relations, and drawing out implications for theory.

The idea of performativity is associated firmly with Judith Butler's work, originally developed in relation to gender, and more recently turned to the inquiry into public assemblies, such as the Occupy Movement (Butler, 1990, 2015). Her theory of performativity 'challenged categorical understandings of gender, suggesting that gender is constituted (and reconstituted) through ritualized performances of gender norms' (Jenkins and Finneman, 2018: 157). Performativity is often misinterpreted as 
performance: the latter can be understood in theatrical terms - an actor stepping in and out of her role; in the former, such a separation is impossible. Performativity, as Butler defines it, extends beyond the individual's actions, through subjectivity to the conditions that enable the socially meaningful production of gender, and we may add, other phenomena, such as a/the public:

Performativity seeks to counter a certain kind of positivism according to which we might begin with already delimited understandings of what gender, the state, and the economy are. Secondly, performativity works, when it works, to counter a certain metaphysical presumption about culturally constructed categories and to draw our attention to the diverse mechanisms of that construction. Thirdly, performativity starts to describe a set of processes that produce ontological effects, that is, that work to bring into being certain kinds of realities or, fourthly, that lead to certain kinds of socially binding consequences. (Butler, 2010:147)

Applying this approach to audiences, self-organised publics, and the imaginary public helps to draw attention to the technological and social infrastructure involved in the production of these different collectivities. In the context of engagement, seen as a technology for producing forms of collectivity (Pieczka, 2018), the town hall meeting is a good example to unpack performativity in strategic communication in the service of business as well as public interests. Traditionally, a political, civic or community event, the town hall has now emerged also in a digitally enhanced form as a commercial service offered to businesses to improve employee engagement, mixing face-to-face and digital interaction, physically and virtually present audiences.

To continue let us consider fracking, an area that in terms of public relations work my involve public affairs; taken from a citizens' perspective, it may involve the use of communication for activism: in both, collective action and the formation of a sense of collectivity are important. Fracking is a highly polarising policy issue with battles frequently fought locally around the planned or existing production sites (Weible et al, 2016; Doshkin, 2016). These can be conducted in town hall meetings, as happened for example in Protobello, a local community in central Scotland concerned with the Scottish fracking policy (Portobello Community Council, 2015). Such events bring together 
environmentalists, people who live in the neighbourhood, and organizational actors with specific interests. Town hall audiences are produced by sets of rules. For example, the Scottish planning law requires public consultation, particularly for projects of national importance, with an expectation of pre-planning consultation with relevant communities in order to shape the plans (Planning Circular 3/2013). The set of rules that enables and governs Community Councils is part of Scottish government's explicit policy on community empowerment (Community Empowerment, n.d.). While the policy and its consultation in Scotland was about allowing fracking in the first place (Watterson and Dinan, 2018), Portobello as a community was engaged in this process with a clear understanding that should the technology be allowed, fracking might well take place under their feet (Interview with an organizer, 9 November 2017). Spacial proximity to a possible fracking site is a factor in collective action and formation of the local audience (Doshkin, 2016). However, research in environmental policy and communication has also demonstrated the importance of discourse coalitions: these are defined as 'loose networks of actors that develop and sustain a way of interpreting a policy issue' with no need for direct interaction, instead the shared interpretations may be developed 'in public discourse through news media, websites, or the dissemination of reports and the like' (Dodge, 2017: 893). This translates in communication management terms into framing as a strategic communication activity. Thus while those participating in town halls or other consultative events can be treated as audiences; it is important to acknowledge also the independently existing publics created through circulation of texts and 'mere attention', as Warner puts it. One of such widely circulating and influential text for anti-fracking public was Gasland, a 2010 documentary film made by Josh Fox (Vasi el at, 2015) which also played its part in Portobello. This brief example has only begun to illustrate the complex coexistence of the different types of collective entities and the conditions of their performativity. Nevertheless it demonstrates that audiences are not passive, although their performance depends on the existing rules of engagement, so to speak. Publics, on the other hand, are not formed by responding to messages, though circulation of (promotional) content may be a relevant factor. A straightforward relationship between a specific message/text and an individual response is not what publics are about. Publics are about lines of development through time and public discourse. In brief, 
while audiences may be understood, at least partly, in behavioural terms laid out by STP; publics are better approached in cultural terms through the concept of discourse (Motion and Leitch, 1996).

As noted above, performativity and performance should not be confused, nevertheless it is important to consider how being an audience or a public might be performed. Warner pointed to the dependence in our understanding of a public on 'metaphors of conversation, answering, talking back', with very little work done theoretically to 'disentangle public discourse from its self-understanding as conversation' (Warner, 2005: 90). Similarly, Butler argued for the need to look beyond speech as the key to performance of a public : 'How,' she asks 'could we understand a public assembly as a political enactment that is distinct from speech?' (2015:155). In my earlier example I alluded to this problem by claiming that my speechless presence in the lecture audience constituted a mode of performance. Bruno Latour's essay 'From Realpolitik to Dingpolitik, or how to make things public' (2004) also addressed the question of speech in the enactment of the public, turning it into an explicit critique of the model of rationality arising from the legacy of the Enlightenment. Latour pointed to the preoccupation in political philosophy with procedures ('from Hobbes to Rawls, from Rousseau to Habermas'), at the expense of a more 'realistic' understanding of the world to which politics applies: 'Procedures to authorize and legitimate are important...but it's only half of what is needed... The other half lies in issues themselves, in the matters that matter, in the res that creates a public around it.' (2004: 15-16). He thus rejected the model of the public built on the idea of the rational, deliberative, consensus-driven interaction as something of a fiction:

The cognitive deficiency of participants has been hidden for a long time because of the mental architecture of the dome in which the Body Politik was supposed to assemble. We were told that all of us — on entering this dome, the public sphere — had to leave aside in the cloakroom our own attachments, passions and weaknesses. Taking our seat under the transparent crystal of the common good ... we would then be collectively endowed with more acute vision and higher virtue... . Unfortunately those 'palaces of reason' ... are no longer able to house the issues they were supposed to gather. (2004: 30) 
Instead, Latour pointed to the multiplicity of places and ways in which things, matters of public concern, take shape, such as laboratories, churches, financial trading rooms, internet forums, each with its own rules of participation, speaking, and decision making. A multiplicity of public and private organizations are engaged in public matters, as demonstrated by recent battles about privacy and publicness in the communication sector (Van Dijck et al, 2018). Politics, and the public good, we could add, is no longer the provenance of 'properly speaking parliaments' (Latour, 2005: 41). Having escaped the parliamentary ideal chamber, the imaginary public of a democratic society is now to be found, at least partly, in what I call audiences.

How does one, then, perform being a member of an audience or a public? As illustrated earlier, the address contained in public discourse meets with a response from a self-organizing public, but it may also be witnessed by onlookers (Warner, 2005: 63), or 'innocent bystanders', to borrow the term from a discussion of audience in performance art (Frazer, 2012). If speech may reach people indiscriminately and erratically, with unpredictable consequences (Butler, 2015: 62), it may also not be necessary to the performance of a public. Butler (2015: 8-9) argued that embodiment, i.e. bodies in a place, constitutes public action and is a meaningful statements in its own right. This leads us to question the importance given to 'speaking' as the only way of performing a public that counts. Are those who do not or cannot speak not deserving recognition in public relations research or practice as a meaningful entity? Having already loosened the connection between the problem and its public, and having instead connected the public to the circulation of ideas, it follows that there is no such thing as a non-public, that there are no innocent bystanders. The idea that 'messages', routine elements of strategic practice, either hit their target public or can otherwise be discounted, vanishing without trace into a nonsignificant social space off the target appears problematic. Messages, fragments of texts and ideas circulate discursively through culture in ways that are beyond control and therefore cannot be discounted. What organizations say in their public relations voices in one context to a particular audience may be picked up, reinterpreted and re-circulated in a different way—PR gaffes are simple examples to illustrate this point. 
To sum up, the performative approach to the public, in all three sense of the word offered in this paper, is a form of critical reflection focusing on the conditions and processes through which these entities arise as realities. By extension, it also draws attention to realities denied existence. This leads to questions about the kind of audiences or publics that come into being through established public relations' routines of address, and about their reality.

\section{Conclusions}

Public relations inquiry needs to rethink what is meant in the field by a/the public and where this term stands in relation to others, such as stakeholders, digital crowds, networks, or swarms (Lee, 2017). Four implications can be drawn from the discussion offered in this article. Firstly, the model of $a$ public — introduced by Dewey, given a normative shape by Habermas and by much of the work under the aegis of deliberative democracy — is only one way of approaching the matter. Secondly, the idea of the public, as the sovereign totality of people, should neither be abandoned nor approached simply as a matter of scaling up from a public (the public as multiplicity of specific publics) but rather treated as one of the related modalities, ways in which we equivocate between I and we, as Butler put it (2015: 9). Thirdly, a public understood as a communicative procedure can only offer partial understanding of collective ways of acting, and therefore things of shared lives - issues, for example food, financial services, or energy generation — need to find a visible place in the discussion. An example of such an approach where publics and things/issues are treated together in their specific fields (environment, health, science) is illustrated by Kim and Ni's (2013) extension of the Situational Theory of Publics. Finally, issues/problems are assembled rather than given and thus should be treated as emerging from discourses, from the circulation of texts, and relationships between various actors, institutions and technologies.

Consequently, it is proposed that the public be treated in three distinct senses: as a political and social imaginary; as a public of shared spaces; and as a public of shared attention. The first of these retains the totalizing symbolic meaning identified by Warner with collective political entities such the nation or commonwealth, and by Dewey as Great Community. The second, an audience, is a potentially 
more tangible plurality that can appear as bodies in a physical space, for example a town hall meeting or a demonstration where their co-presence is fundamental to the performance of being such a public. Audiences are produced creatively in response to rules governing events or public spaces in which they come together. Audiences come together for a purpose. In this sense, an audience is like a public defined by Cutlip or Grunig and Hunt (see section 'Public relations discovers the public'). The last category, the self-organised public refers to a collective constituted at both subjective and intersubjective levels by individuals directing their attention to ideas that flow through public discourses and are concerned with things that people care about. A public thus exists for a reason (because), rather than a purpose (in order to). These three modalities can be distinct, but they can also shade into one another.

This paper argues for adopting the performative approach to the public in public relations to tackle some of the biases in public relations theory identified by Winkler and Wehemier (2018). The essentialist bias, discussed earlier, could be overcome by treating the public (in all three sense I used in this paper), as a process of enactment rather than a given. The instrumentalist bias, approaching the public as a means for organizations to control their environments, is challenged by the recognition of the nature of circulatory processes that evade ultimate control. Consequently, this paper proposes that the PESO model of communication is a useful starting point for public relations research in search of more complex understanding of formation of the public (in all three senses) in relation to processes of cocreation and circulation of a wide range of text. This argument is not about replacing one way of thinking entirely with another; rather about enriching ways of thinking in public relations.

\section{References}

Aldoory, L and Sha, B-L (2007) Situational theory of publics: Practical applications, methodological challenges and theoretical horizons. In: Toth E (ed) The future of excellence in public relations and communication management: Challenges for the next generation. Mahwah, NJ: Lawrence Erlbaum Associates, pp. 339-355. 
Anderson G and Grinberg J (1998) Educational administration as a disciplinary practice:

Appropriating Foucault's view of power, discourse and method. Educational Administration Quarterly 34(3): 329-352.

Bauman Z and Bordoni, C (2014) The State of Crisis. Cambrdge, UK: Polity Press.

Bennett L and Segerberg, A (2012) The logic of Connective Action. Information, Communication \& Society, 15(5), 739-768.

Bohman J (2004) Expanding dialogue: the internet, public sphere and transnational democracy. In:

Crossley N and Roberts J (eds). After Habermas: New Perspectives on the Public Sphere.

Blackwell, pp. 131-155.

Butler J (1990). Gender Trouble: Feminism and the subversion of identity. New York: Routledge.

Butler J (2010). Performative agency. Journal of Cultural Economy 3(2): 167-161.

Butler J (2015). Notes Toward a Performative Theory of Assembly. Cambridge, MA: Harvard University Press.

Burkart R (2018). On Habermas: Communication and understanding- key concepts in public relations. In: Ihlen Ø and Fredriksson M (eds) Public Relations and Social Theory: Key figures, concepts and issues ( $2^{\text {nd }}$ ed). London: Routledge, pp: 272-292.

Calhoun C (11 April 2013) The Problematic Public Revisiting Dewey, Arendt, and Habermas. The Tanner Lectures on Human Values. Delivered at University of Michigan. Available at https://tannerlectures.utah.edu/Calhoun\%20Tanner\%20Lecture.pdf

Carey J (1989) Communication as Culture: Essays on Media and Society. New York: Routledge. Castells M (1996) The Rise of Network Society. Oxford: Blackwell Publishing.

Community Empowerment (nd) Scottish Government. Available at

https://www.gov.scot/policies/community-empowerment/community-councils/

Cutlip S and Center A (1978) Effective Public Relations (5th ed). Englewood Cliffs, NJ: Prentice Hall.

Demetrious K (2013) Public Relations, Activism and Social Change. London: Routledge. 
Demetrious K and Surma A (2019) In ordinary places: The intersections between public relations and neoliberalism: Special Issue , Public Relations Inquiry, 8(2), 105-108.

Dewey J (1927/2012). The Public and its Problems. Philadelphia, PA: Pennsylvania State University Press.

Dietich G (2014) Spin Sucks: Communication and Reputation Management in the Digital Age. New York: Pearson.

Dietrich G (March 14, 2018) What is the PESO Model? Available at https://contentconnection.prsa.org/resources/articles/what-is-the-peso-model

Dodge J (2017). Crowded Advocacy: Framing Dynamic in the Fracking Controversy in New York. Voluntas, 28(3), 888-915.

Edwards L (2016) The role of public relations in deliberative systems. Journal of Communication, 66: $60-81$.

Edwards L (2018) Understanding Public Relations. London: Sage.

Fawkes J (2016) Professional ethics and the polis: A transcendent function of our times? Atlantic Journal of Communication, 24: 40-49.

Fitch K and L'Etang, J (2017) Other voices? The state of public relations history and historiography: Questions, challenges and limitations of 'national' histories and historiographies. Public Relations Inquiry, 6(1): $115-136$

Foucault M (1979/1991) Discipline and Punish: The Birth of the Prison (translated by Alan Sheridan). London: Penguin Books

Fraser N (1992) Rethinking the public sphere: A contribution to the critique of actually existing democracy. In: Colhoun C (ed). Habermas and the Public Sphere. MIT Press, pp. 109-143.

Frazer, W. (2012). No Innocent Bystanders : Performance Art and Audience. Dartmouth College Press.

Freeman, R. E. (1984) Strategic Management: A Stakeholder Approach. Boston: Pitman.

Goodin R and Dryzek J (2006) Deliberative impacts: The macro political uptake of mini-publics, Politics and Society, 34(2): 219-244. 
Government Communication Service (February 2016). Government communication professional competency framework. Availabe at: https://gcs.civilservice.gov.uk/professionaldevelopment/competency-framework/(accessed 3 April 2018).

Global Capabilities Framework Project (n.d.) KAS list. Available at: http://www.globalalliancepr.org/capabilitiesframeworks/(accessed 2 April 2018).

Grunig J (2011) Public relations and strategic management: Institutionalizing organization-public relationships in contemporary society, Central European Journal of Communication, 1: 1131.

Grunig JE and Hunt T (1984) Managing Public Relations. New York: Holt, Rinehart and Winston. Grunig, JE and Repper FC (1992) Strategic management, publics, and issues. In: Grunig J E (ed), Excellence in Public Relations and Communication Management. Hillsdale, NJ: Lawrence Erlbaum Associates, pp. 117- 157.

Habermas J (2006) Political Communication in Media Society: Does Democracy Still Enjoy an Epistemic Dimension? The Impact of Normative Theory on Empirical Research. Communication Theory 16: 411-426.

Habermas J (2002) On the Pragmatics of Communication (edited by M. Cooke). Cambridge: Polity. Habermas J (1996) Between Facts and Norms: Contributions to a Discourse Theory of Law and Democracy. Cambridge, MA: MIT Press.

Habermas J (1984) The Theory of Communicative Action. Vol. I: Reason and the Rationalization of Society, T. McCarthy (trans.). Boston: Beacon.

Jackall R and Hirota J (2000) Image Makers: Advertising, Public Relations and the Ethos of Advocacy. Chicago: Chicago University Press.

Jenkins J and Finneman T (2018) Gender trouble in the workplace: applying Judith Butler's theory of performativity to news organizations. Feminist Media Studies, 18(2), 157-172.

Johnston J and Pieczka M (2019) Public interest communication: a framework for systematic inquiry. In: Johnston, J and Pieczka M (eds). Public Interest Communication. London: Routledge.

Kim J-N, and Ni L. (2013) Conceptualizing publics and constructing public relations theory: the Situational Theory of Problems Solving and its new research. In: K Sriramesh, A Zerfass 
and J-N Kim (eds). Public Relations and Communication Management: Current Trends and Emerging Topics. New York: Routledge: pp. 126-142.

Kim J-N, Ni L. and Sha B-L (2008) Breaking down the stakeholder environment: explicated approaches to the segmentation of publics in public relations research. Journalism and Mass Communication Quarterly, 85(4): 751-768.

Larsson L (2006) Public relations and democracy: a Swedish perspective. In: L’Etang J and Pieczka M (eds). Public Relations: Critical Debates and Contemporary Practice. Mohwah, NJ: Lawrence Erlbaum Associates, pp.123-142.

Latour B (2005) From Realpolitik to Dingpolitik: or how to make things public. In: Latour B and Weibel P (eds) Making Things Public: Atmospheres of Democracy. ZKM/ Centre for Arts and Media, Karlsruhe, and MIT Press, Cambridge, MA, pp. 14-43.

Lee RLM (2017) Do online crowds really exist? Proximity, connectivity and collectivity, Distinktion: Journal of Social Theory, 18(1), 82-94.

Leitch S and Neilson D. (2001) Bringing publics into public relations. In Heath R (ed.) Handbook of Public Relations. Sage, Thousand Oaks, CA, pp. 127-138.

Lippmann W (1922). Public Opinion. New York: Harcourt, Brace and Company.

Lippmann W (1925). The Phantom Public. New York: Harcourt, Brace.

Lovari A and Parisi L (2015) Listening to digital publics. Investigating citizens' voices and engagement within Italian municipalities’ Facebook pages, Public Relations Review (41) $205-213$.

MacIntyre A (1981) After Virtue. London: Gerald Duckworth \& Co.

Macnamara J, Lwin M, Adi A and Zerfass A (2016) 'PESO' media strategy shifts to 'SOEP': Opportunities and ethical dilemmas, Public Relations Review, (42) 377-385.

Mackey S (2006) Misuse of the term 'stakeholder' in public relations. PRism 4(1). Available at http://www.prismjournal.org/fileadmin/Praxis/Files/Journal_Files/2006_general/Mackey.pdf (accessed 20 September 2017).

McKie D and Munshi D (2007) Reconfiguring Public Relations: Ecology, Equality and Enterprise. London: Routledge. 
Macleod A (2007) Invisible hand arguments: Milton Friedman and Adam Smith. The Journal of Scottish Philosophy, 5(2): 103-113.

Mansbridge J, Hartz-Karp J, Amengual M and Gastil J (2006) Norms of deliberation: An inductive study. Journal of Public Deliberation, 2(1). Available at https://www.publicdeliberation.net/jpd/vol2/iss1/art7/(accessed 3 March 2018)

Mason L (2017) The Dewey-Lippmann debate and the role of democratic communication in the Trump age. Dewey Studies, 1(1): 79-110.

Motion J and Leitch S (1996). A discursive perspective from New Zealand: Another world view. Public, Relations Review, 22, 297-309.

Myers C (2017) United States Antecedents and Proto-PR. In T Watson (ed) North American perspectives on the Development of Public Relations. London: Palgrave Macmillan, pp. 5-19.

Olson M (1965) The Logic of Collective Action: Public Goods and the Theory of Groups, Cambridge, MA Harvard University Press

Peters JD (1989) Democracy and American Mass Communication Theory: Dewey, Lippmann, Lazarsfeld, Communication 11: 199-220.

Pieczka M (2018). On Bauman: power, ethics and social hermeneutics. In: Ihlen Ø and Fredriksson M (eds) Public Relations and Social Theory: Key Figures, Concepts and Issues ( $2{ }^{\text {nd }}$ ed.). London: Routledge, pp. 61-79.

Pieczka M (2018) Critical perspectives of engagement. In K Johnston and M Taylor (eds) The Handbook of Communication Engagement. Hoboken, NJ: Wiley-Blackwell, pp. 549-568.

Planning Circulr3/2013: Development Management Procedures (27 December 2013). Scottish Government. Available at https://www.gov.scot/publications/planning-series-circular-3-2013development-management-procedures-2/ (Accessed 1 July 2019).

Plowman KD, Wakefield RL and Winchel B (2015) Digital publics: Tracking and reaching them. Public Relations Review, 41, 272-277.

Our Forth Public Meeting - Fracking and Unconventional Gas in Portobello (January 30, 2015). Portobello Community Council [website]. Available at 
http://www.portobellocc.org/pccpn/2015/01/30/our-forth-public-meeting-fracking-and-

unconventional-gas-in-portobello/ (Accessed 1 July 2019).

Price V (2008) The public and public opinion in political theories. In W Donsbach and M W Traugott (eds) The Sage Handbook of Public Opinion Research, pp. 11-23.

Rakow L (2018). On Dewey: Public relations and its eclipse of The Public. In: Ihlen Ø and Fredriksson M (eds) Public Relations and Social Theory: Key Figures, Concepts and Issues ( $2^{\text {nd }}$ ed.). London: Routledge, pp. 315-333.

Rawlins B (March 2006). Prioritizing Stakeholders for Public Relations [Gold Standard Paper of the Commission on Public Relations Measurement]. Institute for Public Relations. Available at https://instituteforpr.org/prioritizing-stakeholders/ (accessed 2 March 2018).

Reed IA (2017) Ethnography, theory, and sociology as a human science: An interlocution. Ethnography, 18(1): 107-129.

Rogers M (2012) Introduction: revisiting the public and its problems. In J. Dewey. The Public and its Problems. University Park, PA: Pennsylvania State University, pp. 1-29.

Schliesser E (2017) Adam Smith: Systematic Philosopher and Public Thinker. Oxford: Oxford University Press.

Schudson M (2008) The 'Lippmann-Dewey Debate' and the invention of Walter Lippmann as an antidemocrat 1986-1996, International Journal of Communication, 2: 1031-1042

St John B and Lamme M (2011) The evolution of an idea: Charting the early public relations ideology. Journal of Communication Management, 15(3): 223-235.

Stoker K (2014) Defining public in public relations. In: St. John III B, Lamme, M and L'Etang, J (eds). Pathways to Public Relations: Histories of Practice and Profession. London: Routledge, pp.340-351.

Thomassen, JJA. (2015). What's gone wrong with democracy, or with theories explaining why it has? In T. Poguntke, S. Rossteutscher, R. Schmitt-Beck, \& S. Zmerli (Eds.), Citizenship and Democracy in an Era of Crisis. London: Routledge. 
Toledano M (2016) Advocating for reconciliation: Public relations, activism, advocacy and dialogue. Public Relations Inquiry, 5, 277-294.

Van Dijck jJ Powell, T and De Waal, M (2018) The Platform Society. Oxford: Oxford University Press.

Van Ruler B (2004) The communication grid: an introduction of a model of four communication strategies. Public Relations Review 30:123-143.

Vasi IB, Walkerm ET, Johnson JS and Tan HF (2015) “No Fracking Way!” Documentary Film, Discursive Opportunity, and Local Opposition against Hydraulic Fracturing in the United States, 2010 to 2013, American Sociological Review, 80(5) 934-959.

Vasquez, MG and Taylor M (2001) Research perspectives on 'the public'. In: Heath R (ed.)

Handbook of Public Relations. Thousand Oaks, CA: Sage, pp. 139-154.

Warner M. (2005) Publics and Counterpublics. New York: Zone Books.

Watterson A and Dinan W (2018) Public Health and Unconventional Oil and Gas Extraction Including Fracking: Global Lessons from a Scottish Government Review, International Journal of Environmental Research and Public Health, 15(4), 675-=

Wernick A (1991). Promotional Culture. London: Sage.

Weible CM, Heikkila T, Ingold K, and Fischer M (2016) Policy Debates on Hydraulic Fracturing. Palgrave Macmillan.

Winkler P and Wehmeier S (2018) On Harrison White: Rethinking Relations in Public Relations. In: Ihlen $\varnothing$ and Fredriksson M (eds) Public Relations and Social Theory: Key Figures, Concepts and Issues $\left(2^{\text {nd }}\right.$ ed.). London: Routledge, pp. 137-157.

White H (2008) Identity and Control; How Social Formations Emerge (2 ${ }^{\text {nd }}$ ed). Princeton, NJ: Princeton University Press. 